\title{
Modelling irrigated maize with a combination of coupled-model simulation and uncertainty analysis, in the northwest of China
}

\author{
Y. Li ${ }^{1,2}$, W. Kinzelbach ${ }^{3}$, J. Zhou ${ }^{4}$, G. D. Cheng ${ }^{4}$, and X. $\mathbf{L i}^{4}$ \\ ${ }^{1}$ College of Earth and Environmental Science, Lanzhou University, Lanzhou, 730000, China \\ ${ }^{2}$ School of Information Science and Engineering, Lanzhou University, Lanzhou, 730000, China \\ ${ }^{3}$ Institute of Environmental Engineering, ETH Zurich, Wolfgang-Pauli-Strasse 15, 8093 Zurich, Switzerland \\ ${ }^{4}$ Cold and Arid Regions Environmental and Engineering Research Institute, Chinese Academy of Sciences, \\ Lanzhou, 730000, China \\ Correspondence to: Y. Li (liyan_2007@1zu.edu.cn), W. Kinzelbach (kinzelbach@ifu.baug.ethz.ch), \\ J. Zhou (zhoujian@1zb.ac.cn), G. D. Cheng (gdcheng@1zb.ac.cn), X. Li (lixin@1zb.ac.cn)
}

Received: 11 January 2011 - Published in Hydrol. Earth Syst. Sci. Discuss.: 18 April 2011

Revised: 23 December 2011 - Accepted: 5 May 2012 - Published: 22 May 2012

\begin{abstract}
The hydrologic model HYDRUS-1-D and the crop growth model WOFOST are coupled to efficiently manage water resources in agriculture and improve the prediction of crop production. The results of the coupled model are validated by experimental studies of irrigated-maize done in the middle reaches of northwest China's Heihe River, a semiarid to arid region. Good agreement is achieved between the simulated evapotranspiration, soil moisture and crop production and their respective field measurements made under current maize irrigation and fertilization. Based on the calibrated model, the scenario analysis reveals that the most optimal amount of irrigation is $500-600 \mathrm{~mm}$ in this region. However, for regions without detailed observation, the results of the numerical simulation can be unreliable for irrigation decision making owing to the shortage of calibrated model boundary conditions and parameters. So, we develop a method of combining model ensemble simulations and uncertainty/sensitivity analysis to speculate the probability of crop production. In our studies, the uncertainty analysis is used to reveal the risk of facing a loss of crop production as irrigation decreases. The global sensitivity analysis is used to test the coupled model and further quantitatively analyse the impact of the uncertainty of coupled model parameters and environmental scenarios on crop production. This method can be used for estimation in regions with no or reduced data availability.
\end{abstract}

\section{Introduction}

In semi-arid and arid regions, there is an increasing competition between the limited water resources and the increasing demand for crop irrigation (Molden, 1997; Seckler et al., 1998). The efficient utilization of water in agriculture and tackling the issue of optimal water use are needed to balance water supply and demand (Tuong and Bhuiyan, 1999; Ines et al., 2002). In the last $20 \mathrm{yr}$, irrigation planning methods have switched from the allocation approach, e.g. based on socio-political considerations, to technological ones (Paudyal and Das Gupta, 1990; Raman et al., 1992). The development of mathematical models allows fundamental progress to guide irrigation quantitatively. The accurate estimation of soil moisture change, evaporation, and transpiration is important for determining availability of water resources (Scanlon et al., 2002) and the sustainable management of limited water resources, especially in arid and semiarid regions (e.g. Gartuza-Payán et al., 1998). Variation in available soil moisture is one of the main causes of variation in crop yields (Rodriguez-Iturbe et al., 2001; Shepherd et al., 2002; Anwar et al., 2003; Patil and Sheelavantar, 2004). Meanwhile, actual evapotranspiration is the main variable for water loss in the soil-plant system and determines soil moisture status (Burman and Pochop, 1994; Monteith and Unsworth, 1990). Crops can only absorb the soil moisture that is present within the reach of their roots. Therefore, the root growth algorithm and plant water uptake modules are 
critical to estimate soil moisture and crop production in crop and ecological models. However, these processes are represented in hydrologic models, the coupling of hydrologic and crop growth models are useful for both hydrology and agronomy.

In the last few years numerous scientists have oriented their research towards enhancing the knowledge of the complex interactions between ecological systems and the hydrological cycle, contributing to the development of ecohydrologic models and soil-plant-atmosphere models (Smettem, 2008; De Willigen, 1991; Engel and Priesack, 1993; Diekkrüger et al., 1995; Shaffer et al., 2001; Van Ittersum and Donatelli, 2003). Kendy et al. (2003) evaluated recharge specifically for irrigated cropland using a model in which soil water flow was governed by a tipping-bucket-type mechanism, and actual transpiration was computed based on the soil water condition using a method introduced by Campbell and Norman (1998). By coupling of hydrologic and crop growth models, Eitzinger et al. (2004) studied soil water movement during crop growth processes and concluded that the coupled modeling approach was better than a single model method. Many classical eco-hydrologic models, such as SWAP (Kroes et al., 2008), DSSAT (Jones et al., 2001, 2003), APSIM (Keating et al., 2003), STICS (Brisson et al., 2003) and Expert-N (Sperr et al., 1993; Priesack, 2006), have been mostly performed in the China by comparing the simulated crop production against observations and investigate the effects of soil moisture and nutrient distribution along the vertical soil profile on crop (e.g. Chen et al., 2010; Fang et al., 2010; Jiang et al., 2011; Yang et al., 2010). However, few studies have evaluated the performance of these models in arid region, northwest of China, or at in regions with no or reduced data availability.

Complex eco-hydrologic models can help to understand interactions between water and energy cycle in soil-plantatmosphere systems. However, models have many degrees of freedom (with many parameters, state-variables and non linear relations) and can be made to produce virtually any desired behavior (Hornberger and Spear, 1981). Debates on the reliability of environmental models have emerged both in the academy and among practitioners (Veld, 2000; Lomborg, 2001; Van der Sluijs, 2002). The United States Environmental Protection Agency (EPA)'s science panel found that quantitative evidence must be characterized as having high uncertainties (David, 2008). The International Food Policy Research Institute (IFPRI) had raised about $\$ 460000$ for the modeling, which would have provided insights to help policymakers compare the outcomes of four broad policy scenarios, such as futures with more free trade or green technologies. But Greenpeace's Haerlin and others objected that the models were not "transparent" (Stokstad, 2008). Columbia University published the book titled "Useless Arithmetic: Why Environmental Scientists Can't Predict the Future" (Pilkey and Pilkey-Jarvis, 2007) presented "Quantitative mathematical models used by policymakers and government administrators to form environmental policies are seriously flawed". The main problem is that models are often asked to answer specific questions about the present or future behaviour of the system under uncertainty conditions (e.g. climate change, different environmental scenarios and presumptive boundary conditions of the dynamics). However, the model only can be confirmed or corroborated by demonstrating agreement between observations and predictions. So, we need a combination of model simulation and ensemble statistics to analyse and predict the scientific problem from a probabilistic viewpoint. In this view, uncertainty and sensitivity analysis (UA/SA) can help investigating the propagation of different sources of uncertainties to the output variables through ensemble sampling. UA/SA analysis is used to quantitatively identify the effect of model parameters and structure on the output estimation.

This paper aims to efficiently manage water resources in agriculture and improve the prediction of crop production in arid region. For this purpose, an eco-hydrological model is developed by coupling a HYDRUS model with a WOFOST model and calibration have been conducted in agricultural experimental field, located in arid region, northwest of China. Based on the coupled modeling, we use UA/SA methods to evaluate the coupled model, predict the risk of a crop production loss as irrigation decreases and quantitatively study impact of coupled model parameters and environmental factors change on maize production. This method can be used as reference for predicting the crop production in regions with no or reduced data availability.

\section{Study region and experimental field description}

The Heihe river basin, located in semi-arid and arid region, is the second largest inland river basin in China. The region has a typical temperate continental climate, with the mean annual precipitation and evaporation ranging from 60 to $280 \mathrm{~mm}$ and 1000 to $2000 \mathrm{~mm}$, respectively. The main crops of this region are maize and wheat, and water use efficiency is low. The key to solve water scarcity and ecological problems of this region is effective management of agricultural water resource and of optimization irrigation. So, an agricultural experimental field (latitude $38^{\circ} 51^{\prime} \mathrm{N}$, longitude $100^{\circ} 25^{\prime} \mathrm{E}$, altitude $1519 \mathrm{~m}$ ), which is shown in Fig. 1, is operated by CAS (Chinese Academy of Science) to study the impact of quantitative irrigation on maize growth. The station is managed according to agricultural practices in the Heihe river basin region, including crop rotations (maize and wheat) and flood irrigation.

\subsection{Characterization of the soil properties}

The experimental field was established on a clay loam soil (USDA classification system). To characterize the soil physical properties, five root zone soil samples were extracted 
Table 1. Measured soil textural and bulk density data.

\begin{tabular}{lcccc}
\hline \multirow{2}{*}{ Depth $(\mathrm{cm})$} & \multicolumn{3}{c}{ Textural fractions } & \multirow{2}{*}{ Bulk density $\left(\mathrm{g} \mathrm{cm}^{-3}\right)$} \\
\cline { 2 - 4 } & $2-0.05 \mathrm{~mm}$ & $0.05-0.002 \mathrm{~mm}$ & $<0.002 \mathrm{~mm}$ \\
\hline $5 \mathrm{~cm}$ & 33.86 & 45.44 & 20.70 & 1.43 \\
$15 \mathrm{~cm}$ & 37.60 & 42.53 & 19.87 & 1.379 \\
$30 \mathrm{~cm}$ & 49.69 & 33.87 & 16.44 & 1.483 \\
$55 \mathrm{~cm}$ & 24.56 & 48.65 & 26.79 & 1.571 \\
$85 \mathrm{~cm}$ & 16.61 & 53.68 & 29.71 & 1.644 \\
\hline
\end{tabular}

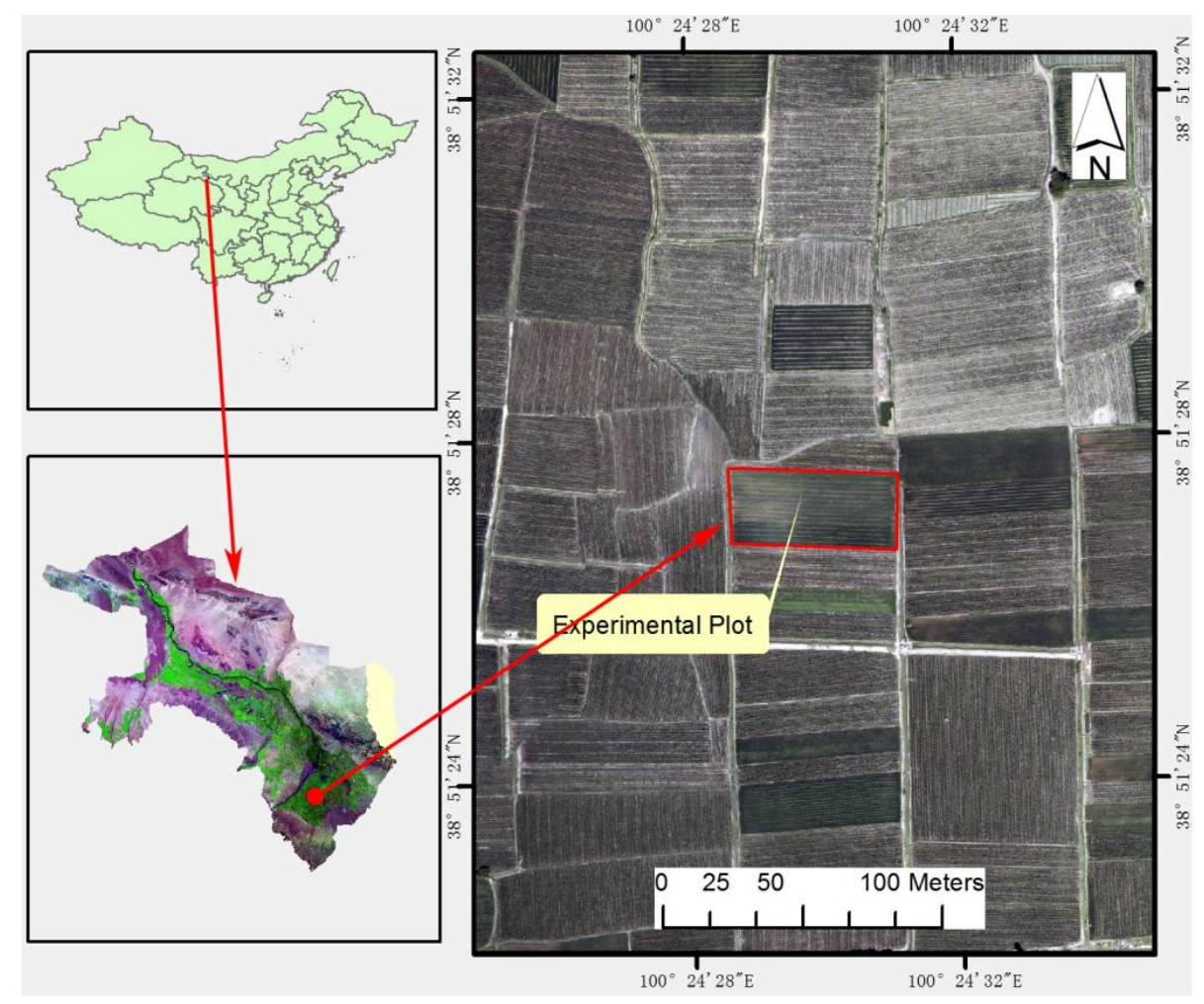

Fig. 1. The location of the experimental plot.

from the ground to a depth of $100 \mathrm{~cm}$. The samples were analyzed in the laboratory to determine soil bulk density (Grossman and Reinsch, 2002), water retention properties (soil water contents at $0-1000 \mathrm{kPa}$ matric potentials) (Equi-pf, New Zealand) and percentages of sand, silt, and clay (Gee and Or, 2002). Saturated conductivity was measured at $10 \mathrm{~cm}, 40 \mathrm{~cm}$ and $100 \mathrm{~cm}$, respectively (Guelph $2800 \mathrm{~K} 1$, USA). The analysis results are shown in Table 1 and Fig. 2. The nitrogen, potassium and phosphorus fertilizer are used $329 \mathrm{~kg} \mathrm{ha}^{-1}$, $220 \mathrm{~kg} \mathrm{ha}^{-1}, 87 \mathrm{~kg} \mathrm{ha}^{-1}$, respectively during maize growth.

\subsection{Field experiment}

The field was instrumented to monitor soil water dynamics in the root zone and the groundwater table. The instrumentation consisted of time-domain reflectometers (TDR) (CS616,
Cambell Scientific, USA) for soil moisture measurements and groundwater observation wells. The depth of soil moisture measurements was $10 \mathrm{~cm}, 20 \mathrm{~m}, 40 \mathrm{~cm}, 60 \mathrm{~cm}, 80 \mathrm{~cm}$, $100 \mathrm{~cm}$, respectively and the data were collected every hour.

The agricultural field was intensively monitored throughout the study period, which lasted from 20 April through 22 September 2009. The field was cultivated with maize and quantitatively irrigated. The field was irrigated 9 times throughout the period of crop growth. The water amount of irrigation is approximately $100 \mathrm{~mm}$ each time. The sowing date, emergence date and harvest date were 20 April, 6 May and 22 September respectively. Meanwhile, the data of Leaf area index (LAI) were measured once every 15 days by LAI2200 instrument. Dry weight of storage organs, dry weight of total above-ground biomass and crop height were measured every 15 days by samples during crop growth. 


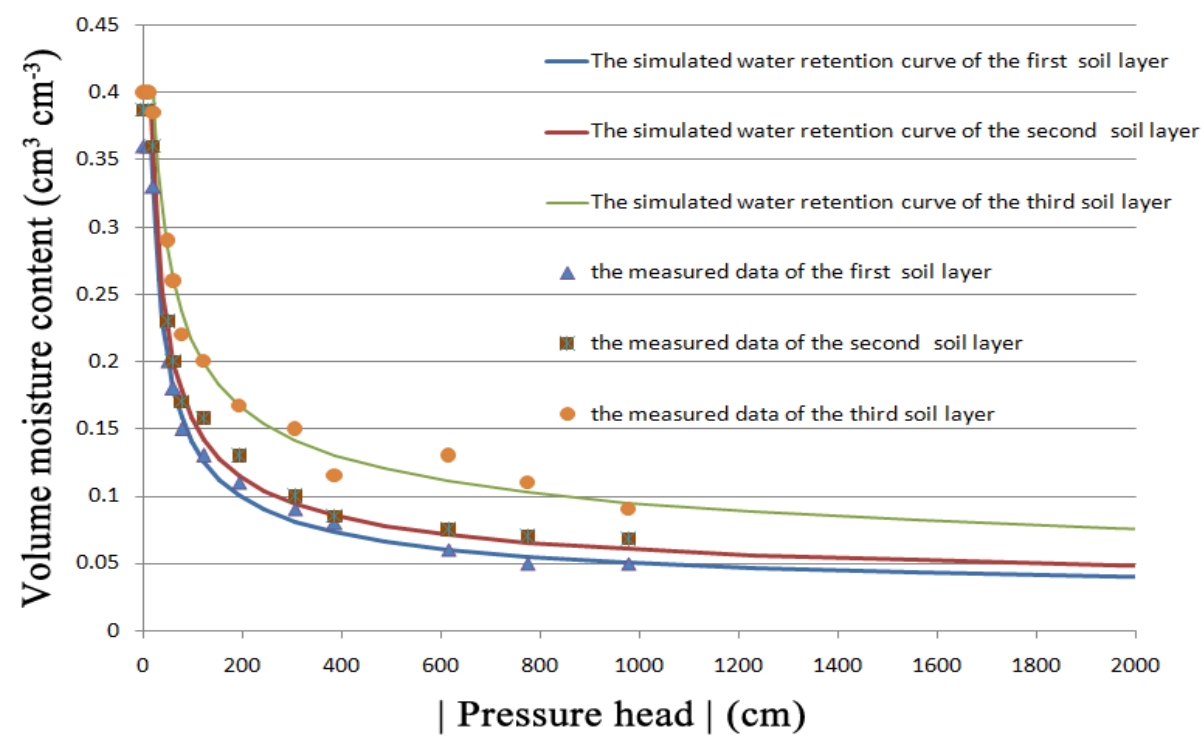

Fig. 2. Comparison between the fitted water retention curve and the measured data in the laboratory.

Half-hourly meteorological data were recorded by the meteorological station (Milos520, Vaisala Co, Finland), located in the experimental field. Available data were net radiation, solar radiation, maximum air temperature, minimum air temperature, precipitation, wind speed, atmospheric pressure, and relative humidity. We measured latent heat during crop growth using eddy covariance systems (EC) (Li7500 \& CSAT3, Cambell Scientific, USA). The correction of EC data was produced with revised EdiRE software from the University of Edinburgh (Xu et al., 2008).

\section{Materials and methods}

\subsection{Crop growth model}

The numerical software, WOFOST (Van Keulen and Wolf, 1986; Boogaard et al., 1998), is a very useful code for determining the production potential, optimizing crop management and quantifying yield gaps of various crops (e.g. wheat, maize, potatoes) (Van Laar et al., 1997; Bouman et al., 2001; Wolf, 2002). The code can also be used to study the effects of environmental variability and climatic change on crop production (Kropff et al., 1996; Berge et al., 1997; Tsuji et al., 1998; Matthews and Stephens, 2002). However, in the waterlimited situation, the soil water balance is calculated using a tipping bucket approach with three compartments, i.e. a root zone, a transmission zone, and a groundwater zone. The potential evapotranspiration is estimated with the PenmanMonteith equation (Monteith, 1965, 1981). The actual crop uptake from soil is calculated as the product of the potential evapotranspiration, a crop factor and a water stress factor. It is relatively simple and not accurate for the hydrologic cycle simulation during crop growth (Eitzinger et al., 2004;
Priesack et al., 2006). A detailed model description can be found in Boogaard et al. (1998).

\subsection{Hydrologic model}

HYDRUS-1-D (Šimůnek et al., 2005) has an advantage in simulating water flow and root water uptake. The simulation is based on the following assumptions: (i) the soil is homogeneous and isotropic, (ii) the air phase does not affect liquid flow processes, and (iii) moisture movement due to thermal gradients is negligible. So, the governing equation for water flow is the 1-D Richards equation:

$$
\frac{\partial \theta}{\partial t}=\frac{\partial}{\partial x}\left[K\left(\frac{\partial h}{\partial x+1}\right)\right]-S
$$

where $h$ is soil water pressure head (L); $\theta$ represents volumetric water content $\left(\mathrm{L}^{3} \mathrm{~L}^{-3}\right) ; t$ is time $(\mathrm{T}) ; x$ is the vertical space coordinate $(\mathrm{L}) ; K$ is the unsaturated hydraulic conductivity $\left(\mathrm{L} \mathrm{T}^{-1}\right)$; and $S$ represents a sink term $\left(\mathrm{L}^{3} \mathrm{~L}^{-3} \mathrm{~T}^{-1}\right)$, defined as the volume of water removed from a unit volume of soil per unit time due to plant water uptake. The sink term is specified in terms of a potential water uptake rate and a stress factor (Feddes et al., 1978):

$$
S=\frac{\alpha(h) R(z)}{\int_{0}^{l r} \alpha(h) R(z) \mathrm{d} z} T_{\mathrm{P}}
$$

where $S$ is the root water uptake rate $\left(\mathrm{L}^{3} \mathrm{~L}^{-3} \mathrm{~T}^{-1}\right) ; R(z)$ is the distribution function of the root; $l r$ is the depth of root $(\mathrm{L}) ; T_{\mathrm{P}}$ is potential transpiration $(\mathrm{L})$; the dimensionless water stress response function $\alpha(h)(0 \leq \alpha(h) \leq 1)$ prescribes the reduction in uptake that occurs due to drought stress. For 


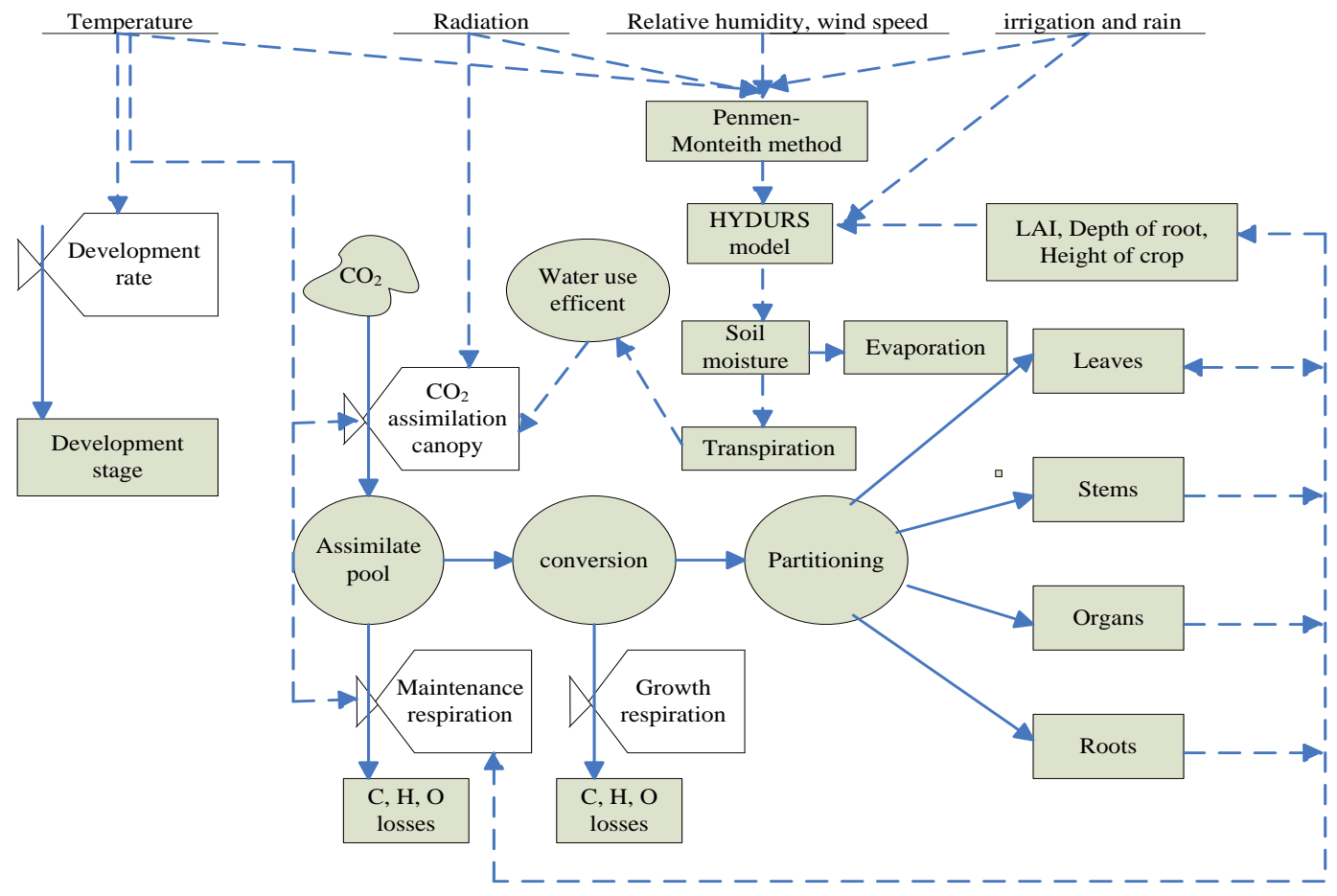

Fig. 3. Flow chart of the coupled HYDRUS and WOFOST models.

$\alpha(h)$, we use the functional form introduced by Feddes et al. (1978):

$\alpha(h)=\left\{\begin{array}{ll}\left(h-h_{4}\right) /\left(h_{3}-h_{4}\right) & h_{4}<h \leq h_{3} \\ 1 & h_{3}<h \leq h_{2} \\ \left(h-h_{1}\right) /\left(h_{2}-h_{1}\right) & h_{2}<h \leq h_{1} \\ 0 & h \leq h_{4}, h>h_{1}\end{array}\right\}$

where $h_{1}, h_{2}, h_{3}$, and $h_{4}$ are threshold parameters. The uptake is at the potential rate when the pressure head is between $h_{2}$ and $h_{3}$. It drops off linearly when $h>h_{2}$ or $h<h_{3}$. The uptake rate becomes zero when $h<h_{4}$ or $h>h_{1}$. Cropspecific values for these parameters are chosen from the database contained in HYDRUS-1D (Šimůnek et al., 2005).

An atmospheric boundary condition is implemented at the soil surface. The atmospheric boundary conditions required daily irrigation, precipitation rates, potential evaporation and transpiration rates as inputs. The detailed description about how to calculate potential evaporation and transpiration can be found in HYDRUS-1-D (Šimůnek et al., 2005). Meanwhile, a deep drainage condition is used at the bottom. The condition require the initial reference groundwater depth to be given (Šimůnek et al., 2005).

The soil hydraulic properties are modeled using the van Genuchten-Mualem constitutive relationships (Mualem, 1976; Van Genuchten, 1980):

$\theta(h)=\left\{\begin{array}{ll}\theta_{\mathrm{r}}+\frac{\theta_{\mathrm{s}}-\theta_{\mathrm{r}}}{\left[1+\left(\alpha h_{\mathrm{c}}\right)^{n}\right]^{1-1 / n}} & h<0 \\ \theta_{\mathrm{s}} & h \geq 0\end{array}\right\}$

$$
\begin{aligned}
K(h) & =K_{\mathrm{s}} S_{\mathrm{e}}^{l}\left\{1-\left[1-S_{\mathrm{e}}^{n /(n-1)}\right]^{1-1 / n}\right\}^{2} \\
S_{\mathrm{e}} & =\frac{\theta(h)-\theta_{\mathrm{r}}}{\theta_{\mathrm{s}}-\theta_{\mathrm{r}}}
\end{aligned}
$$

where $S_{\mathrm{e}}$ is effective saturation and $\theta_{\mathrm{s}}$ is saturated water content $\left(\mathrm{L}^{3} \mathrm{~L}^{-3}\right) ; \theta_{\mathrm{r}}$ is residual water content $\left(\mathrm{L}^{3} \mathrm{~L}^{-3}\right) ; K_{\mathrm{S}}$ is saturated hydraulic conductivity $\left(\mathrm{L} \mathrm{T}^{-1}\right) ; \alpha$ is the air entry parameter; $n$ is the pore size distribution parameter; and $l$ is the pore connectivity parameter. The parameters $\alpha, n$, and $l$ are empirical coefficients that determine the shape of the hydraulic functions. To reduce the number of free parameters, we take $l=1$, a common assumption which is based on Mualem's (1976) study result.

\subsection{Coupling of the model}

The coupling has been performed at a daily scale. Coupling process is shown in the Fig. 3:

1. The irrigation and precipitation, the daily net radiation, the daily maximum and minimum temperatures, the daily wind speed and the daily relative humidity are the input terms in the HYDRUS model.

2. The potential evaporation and transpiration are calculated by the Penman-Monteith combination method in the HYDRUS model.

3. The water uptake is calculated according to Feddes equation in the HYDRUS model. 
4. The soil water balance, soil moisture and groundwater depth are calculated using the HYDRUS model.

5. The root water uptake and actual transpiration on a daily basis are assumed the same, because the most root water uptake is consumed by crop transpiration. Therefore, the ratio between calculated actual water uptake based on Feddes equation and potential transpiration based on Penman-Monteith method is regarded as an indicator for the degree of water stress.

6. The potential daily total gross $\mathrm{CO}_{2}$ assimilation of the crop, which is calculated according to the WOFOST model, is multiplied by the water stress ratio to calculate the actual daily $\mathrm{CO}_{2}$ assimilation. Then, carbohydrate allocation among different crop parts is calculated according to the WOFOST model.

7. The calculated vegetation parameters from the WOFOST $^{1}$ model, more specifically rooting depth, height of the crop and LAI, are then used as inputs for the HYDRUS model at the next step.

\subsection{Sensitivity analysis}

Sensitivity analysis determines the contribution of each input factor to the uncertainty of the outputs. Sensitivity analysis is evaluated using a two-step method: the screening method proposed by Morris (1991) and a variance-based technique proposed by Sobol (1993). The Morris method provides a qualitative assessment of the importance of each input factor, while the Sobol' method performs a quantitative analysis of sensitivity and uncertainty. This two-step methodology has been used in recent studies of input-output relationship and model evaluation (Fox et al., 2010; Jawitz et al., 2008; Muñoz-Carpena et al., 2010).

The one-factor-at-a-time Morris (Morris, 1991) method is particularly effective to screen a subset of relevant parameters among those contained in models with a large number of parameters or with time consuming simulations. The method calculates a set of incremental ratios ( $\Delta$ output/ $\Delta$ parameter) at various points of the parameters space and to obtain means ( $\mu^{*}$; calculated on absolute values) and standard deviations $(\sigma)$ of these ratios. A large value of $\mu^{*}$ belongs to a parameter with an important overall influence (total effect), whilst a large value of $\sigma$ indicates nonlinearities in model response or interactions with other parameters.

Sobol's method (Sobol, 1993) is a variance-based method. The method is modified by Saltelli (2002) by decomposing the output variance into terms of increasing dimensions (i.e. partial variances), representing the contribution of single parameters, and of groups of parameters to the overall uncertainty of the model output. This method allows the simultaneous exploration of the parameter space via a Monte

\footnotetext{
${ }^{1}$ WOFOST model is revised to output Crop Height with equation: Crop height $=281.4 /\{1+\exp [-0.00310 \times($ TSUM-1281.3 $)]\}$
}

Carlo method. Statistical estimators of partial variances are provided by quantifying the relevance of parameters and parameter groups through multi-dimensional integrals. The advantage of Sobol's method is that it allows the simultaneous computation of the first order and total order effect indices for a given parameter. A main sensitivity index $\left(S_{x}\right)$ quantifies the first order effect of a parameter. A total sensitivity index $\left(S_{\mathrm{T} x}\right)$ quantifies the overall effect of a parameter (i.e. including all the possible interactions).

\section{Results and discussion}

\subsection{Model validation}

Running the coupled model requires atmospheric (minimum temperature, maximum temperature, irradiation, vapor pressure, wind speed and precipitation) and irrigation conditions at a daily scale, the parameters of crop characteristics (including parameters referring to, among other things, phenology, assimilation and respiration characteristics, and partitioning of assimilates to plant organs) and the soil hydraulic parameters $\left(\theta_{\mathrm{r}}, \theta_{\mathrm{s}}, \alpha, n, K_{\mathrm{s}}\right)$.

The meteorological data are acquired by the meteorological station. The amounts and times of irrigation are recorded. The parameters of crop characteristics choose the maize data (MAG 203) provided by the European Community (BoonsPrins et al., 1993). An atmospheric boundary condition is implemented at the soil surface. The potential evaporation and transpiration rates are calculated by the meteorological data and the parameters of the crop growth (LAI and height of the crop), which are shown in Fig. 4. The soil profile is divided into three layers in vertical direction according to the soil physical properties. The fist layer is from the ground to a depth of $30 \mathrm{~cm}$. The second layer and the third layer are from a depth of $30 \mathrm{~cm}$ to a depth of $60 \mathrm{~cm}$ and from a depth of $60 \mathrm{~cm}$ to a depth of $100 \mathrm{~cm}$, respectively. The measured relation between pressure head and water content and percentages of sand, silt, and clay for three layers are inputted into Rosetta software (Schaap and Bouten, 1996; Schaap et al., 1998) to calculate van Genuchten (1980) model's water retention parameters. The fitted curve and parameters are shown in Fig. 2 and Table 2.

The simulation time is during the cultivation of maize from sowing (20 April 2009) to harvest (22 September 2009), comprising day of year (DOY) 110-265. The computation time step is one day.

The comparison between simulated soil moisture and observed soil moisture is shown in Fig. 5. The NSE values of the soil moisture for the three soil layers are 0.750, 0.699 and 0.842 , respectively. The dry matter accumulation and partition between the various plant organs, the final yield and harvest index are simulated by the coupled model, as shown in Table 3. The observed TAGP (total above-ground dry production), WSO (dry weight of storage organs) and 

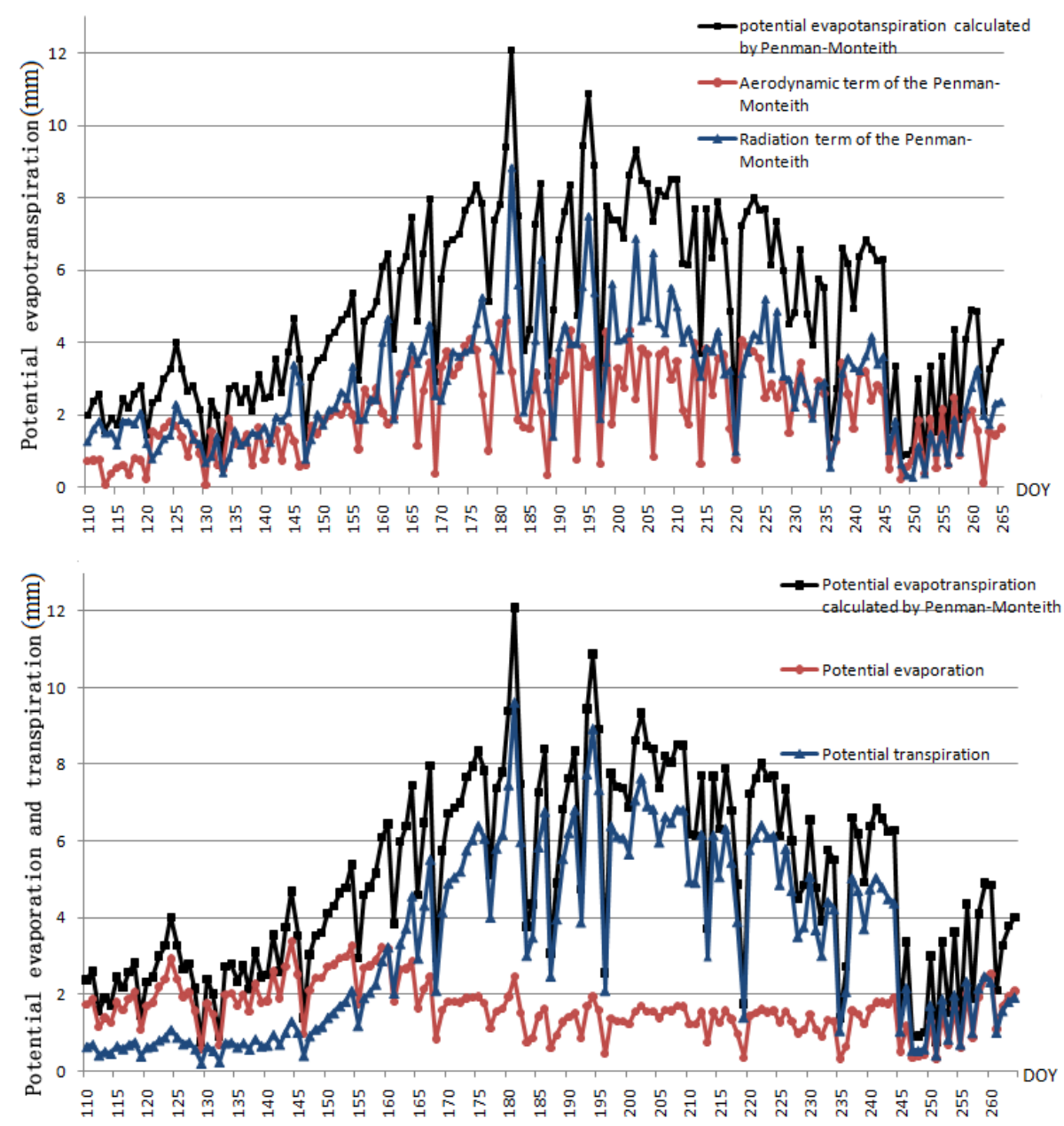

Fig. 4. The estimated potential evapotranspiration, potential evaporation and potential transpiration.

Table 2. The estimated van Genuchten-Mualem parameters of soil hydraulic properties of three layers by ROSETTA.

\begin{tabular}{lccll}
\hline & $\begin{array}{c}\theta_{\mathrm{r}} \\
\left(\mathrm{cm}^{3} \mathrm{~cm}^{-3}\right)\end{array}$ & $\begin{array}{c}\theta_{\mathrm{s}} \\
\left(\mathrm{cm}^{3} \mathrm{~cm}^{-3}\right)\end{array}$ & $\alpha$ & $n$ \\
\hline The first layer $(10 \mathrm{~cm})$ & 0.05 & 0.41 & 0.08 & 0.13 \\
The second layer $(40 \mathrm{~cm})$ & 0.05 & 0.41 & 0.087 & 0.115 \\
The third layer $(100 \mathrm{~cm})$ & 0.05 & 0.41 & 0.11 & 0.10 \\
\hline
\end{tabular}

the LAI (Leaf area index) are compared with the simulation results, which are shown in Figs. 6 and 7. The NSE value of TAGP, WSO and LAI are $0.965,0.978$ and 0.924 , respectively. The results show the simulated dry matter accumulation and partition between the various crop organs match the observations well. The related parameter values are reasonable for local maize characteristics and soil properties in the study field. The comparison between simulated and observed actual evapotranspiration are shown in Fig. 8. The RMSE and NSE values for actual evapotranspiration are $0.721 \mathrm{~mm}$ and 0.783 , respectively. The results show the simulated evapotranspiration also well match the observed evapotranspiration by eddy covariance systems (EC). The simulated evapotranspiration is divided into actual transpiration and actual evaporation. The cumulative simulated actual transpiration is $364 \mathrm{~mm}$. The cumulative simulated actual evaporation is $203 \mathrm{~mm}$. The result reveals that the crop's effective transpiration is approximately 1.79 times the soil evaporation during maize growth under realistic irrigation conditions.

The calibrated model is then used to evaluate the water balance and to search for a potential, water-saving scheme. The number of irrigations remains nine, but the ratio between actual root uptake and potential transpiration is not less than 0.8. The simulated results indicate the maize quantitatively irrigated in $60 \mathrm{~mm}$ water at each would be enough in this region. The simulated water balance under the guided irrigation scheme is compared with the actual irrigation scheme results (Table 4). These results indicate that the guided irrigation scheme can save $350 \mathrm{~mm}$ of irrigation water. Water-saving is mainly due to decreases in deep percolation $(284.2 \mathrm{~mm})$ that accounts for $81.2 \%$ of total 


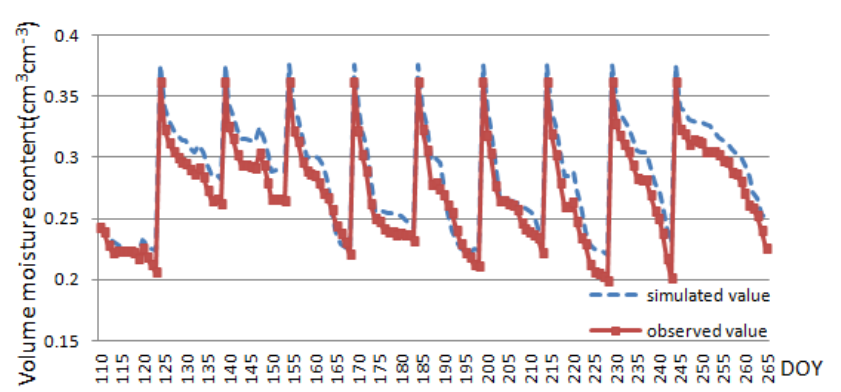

(a) $10 \mathrm{~cm}$ soil moisture

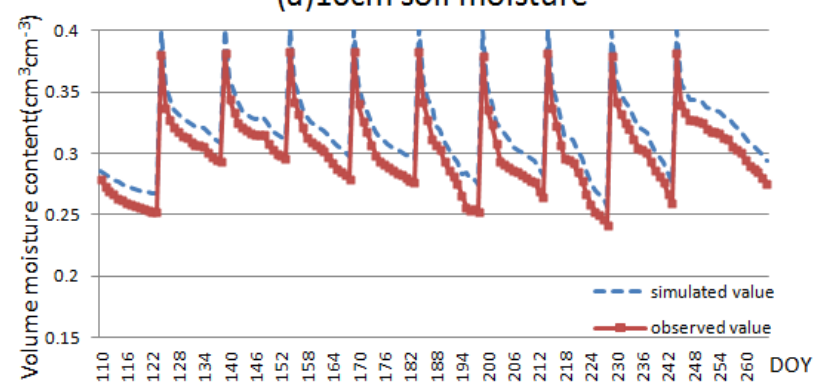

(b) $40 \mathrm{~cm}$ soil moisture

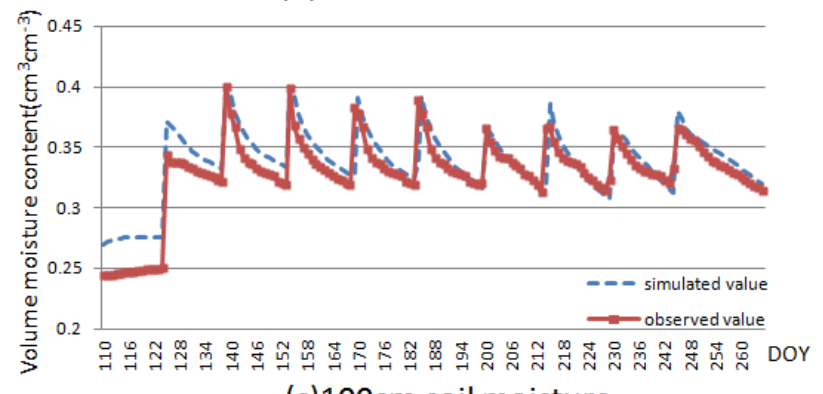

(c) $100 \mathrm{~cm}$ soil moisture

Fig. 5. Comparison between observed soil moisture and simulated soil moisture.

water-saving. The ineffective evaporation decrease $52 \mathrm{~mm}$ that accounts for $14.86 \%$ of total water-saving. Transpiration under the guided irrigation scheme is close to that under actual irrigation scheme. Therefore crop production can be guaranteed, while water is conserved.

\subsection{Sensitivity analysis}

Prior to performing sensitivity analysis, the ranges of the 34 input factors are defined (Table 5) based on values from literature review, experience, research objectives and default, minimum and maximum values of WOFOST and HYDRUS databases. Uniform distributions are assigned to input factors when only the base value is known, the range is considered finite, and no explicit knowledge of the distribution is available (McKay, 1995). This conservative assumption allows an equal probability of occurrence of the input factors along the probability range (Muñoz-Carpena et al., 2010). We divide the parameters into 13 groups according to physical

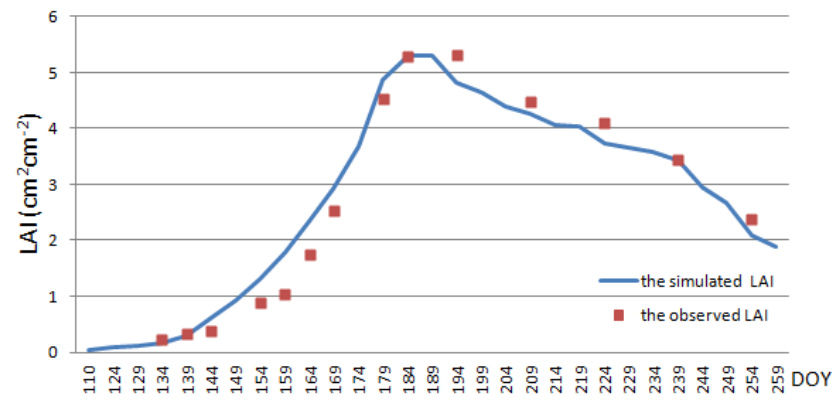

Fig. 6. Comparison between simulated and observed LAI.

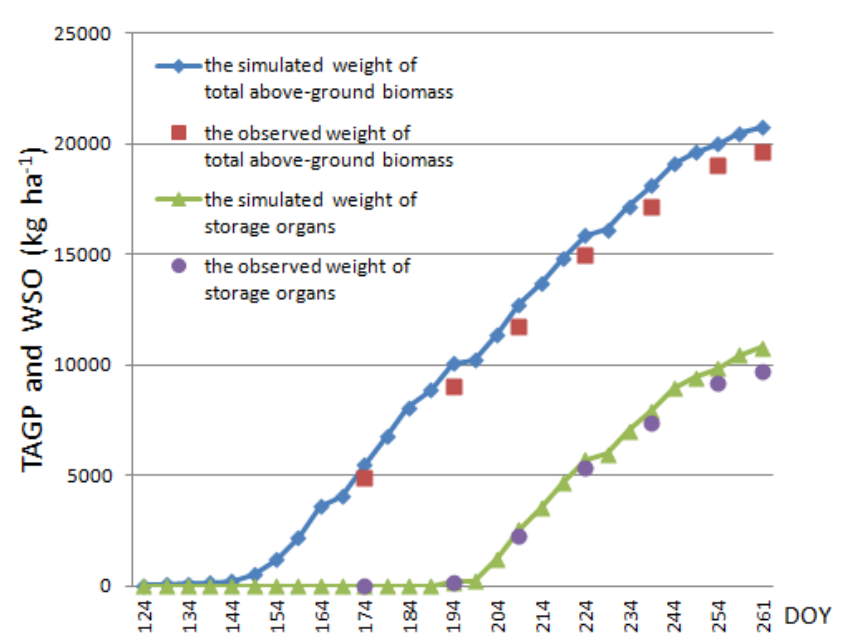

Fig. 7. Comparison between simulated and observed weight of total above-ground biomass and weight of storage organs.

properties and functions. The groups of parameters and the value ranges of all parameters are shown in Table 5.

One model output for weight of storage organs (WSO) at physiological maturity is considered in this analysis because it is a synthetic representation of the numerical model's results. The variation of WSO in response to variations of the crop and environment parameters are investigated using Morris and Sobol's sensitivity study methods, based on SimLab Dynamic Link Library (http://simlab.jrc.ec.europa.eu/), integrated in the coupled HYDRUS and WOFOST models.

For Morris method, the means and standard deviations of the sensitivity parameters $\left(\mu^{*}, \sigma\right)$ for each factor are obtained from 320 samples using the total range of trajectories (10) and levels (4) (Saltelli et al., 2004). For Sobol' method, Monte Carlo sample size is set to 5000 for each factor.

The guided irrigation scheme (Each time $60 \mathrm{~mm}$ of water is applied to maize, in total 9 times) is explored in this study. Figure 9 displays graphically the average strength $\left(\mu^{*}\right)$ and spread $(\sigma)$ of model response (change of yield) to the variation of parameters according to their various functions of crop growth (phenology, assimilation, respiration, conversion, etc.) and environment factors (sowing 


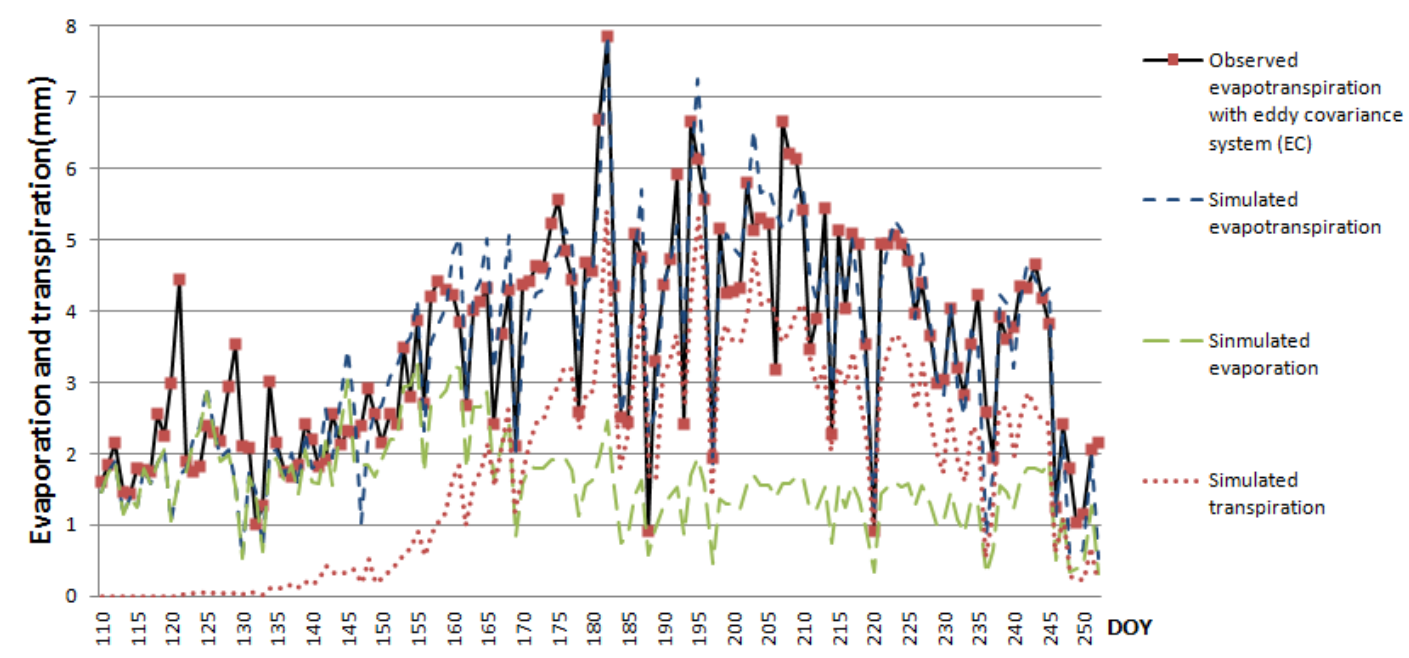

Fig. 8. Comparison between simulated and observed actual evapotranspiration.

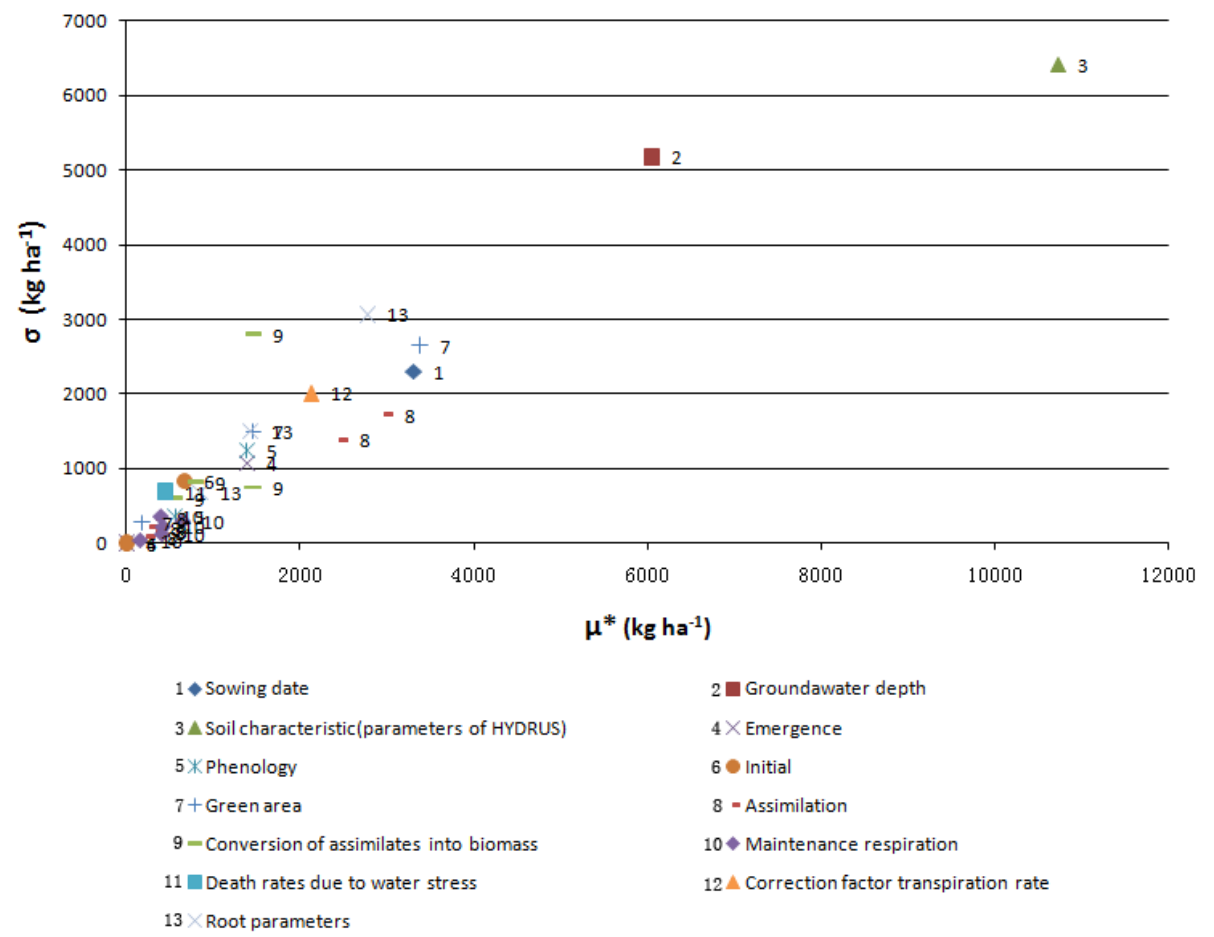

Fig. 9. Graph displaying the Morris sensitivity measures $\mu^{*}$ and $\sigma$ for 13 groups of parameters.

date, groundwater depth, soil characteristics, etc.). The parameters are ranked in descending order of the $\mu^{*}$ values, which are shown Table 6 . The screening carried out with the Morris method allows identifying 13 out of 33 parameters $(40 \%)$ as not relevant. Each parameter causes a yield change less than $500 \mathrm{~kg} \mathrm{ha}^{-1}$, which approximately accounting for $5 \%$ of the total output $10777 \mathrm{~kg} \mathrm{ha}^{-1}$. The 12 out of 33 parameters $(36 \%)$ are identified with an effect between 500 and $2000 \mathrm{~kg} \mathrm{ha}^{-1}$. The 8 out of 33 parameters $(24 \%)$ have an effect greater than $2000 \mathrm{~kg} \mathrm{ha}^{-1}$ (including HYDRUS parameters, ZIT, SLATB1, IDSOW, EFFTB, RDMCR, KDIFIB, CFET). Further, $\sigma$ indicates that interaction, correlation and non-linearity are relevant for coupled model.

We also analyze the distribution of simulated yields with Monte Carlo methods to gain information about the reaction of maize production to the variations of the parameters under various irrigation schemes. The Monte Carlo sample size is set to 5000. Four scenarios are proposed. In the four scenarios the single application of irrigation-water is respectively 

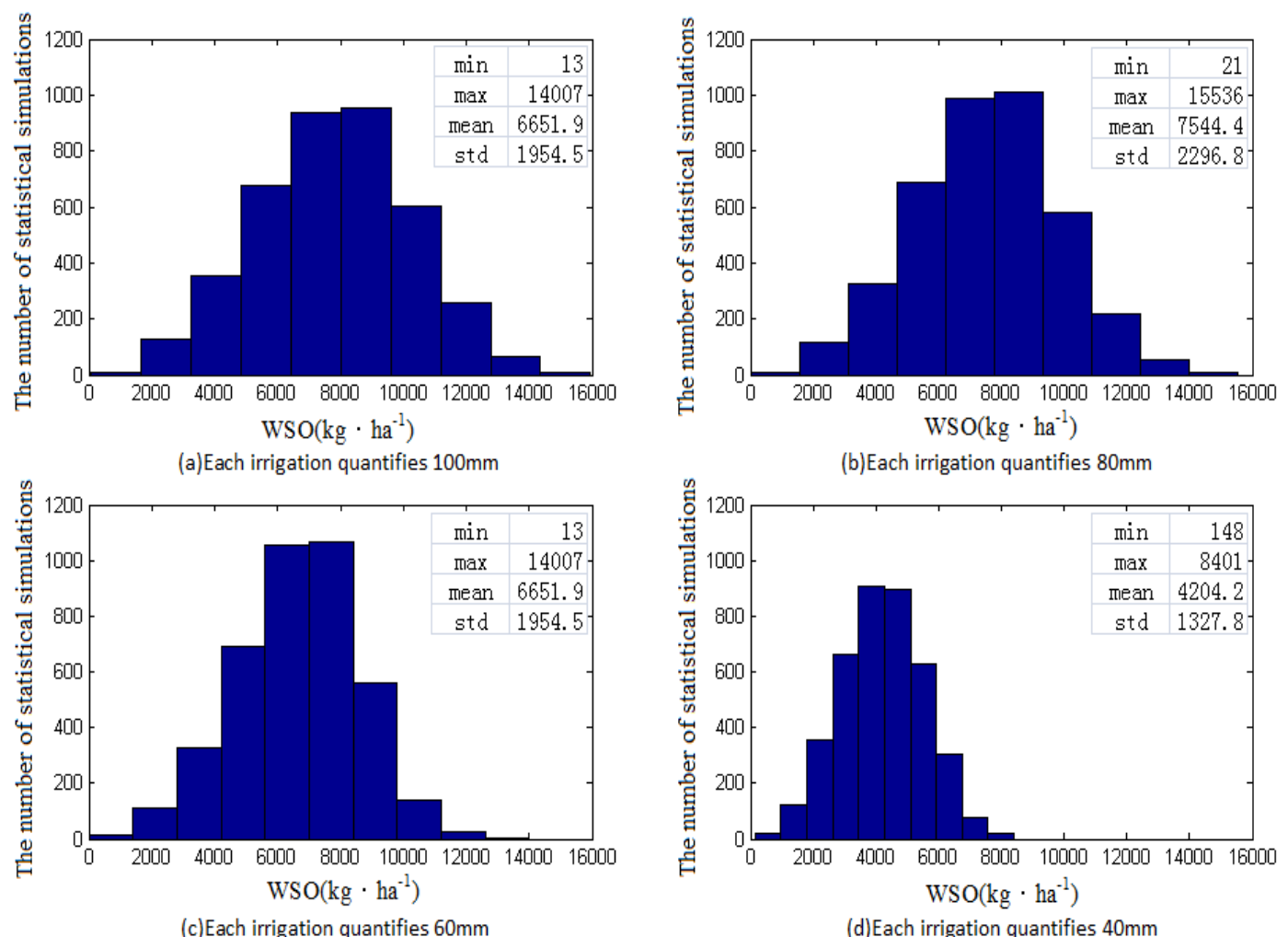

Fig. 10. Histograms of the output distributions in four different irrigation scenarios.

assumed to be $40 \mathrm{~mm}, 60 \mathrm{~mm}, 80 \mathrm{~mm}$ and $100 \mathrm{~mm}$ for a total of 9 irrigation times. The uncertainty analysis is performed. The results are shown in Fig. 10, which reveal the risk of crop production loss with decrease of irrigation. The average crop production increases from $4204.2 \mathrm{~kg} \mathrm{ha}^{-1}$ in the case where each irrigation-water is $40 \mathrm{~mm}$ to $7781.2 \mathrm{~kg} \mathrm{ha}^{-1}$ in the case where each irrigation-water is $100 \mathrm{~mm}$. When each irrigation- water is more than $60 \mathrm{~mm}$, the distribution of simulated yields is mainly between $5500 \mathrm{~kg} \mathrm{ha}^{-1}$ and $11000 \mathrm{~kg} \mathrm{ha}^{-1}$, which account for $85 \%$ realizations. This method can predict probability of crop production in uncertain range of crop parameters and environment parameters.

The Sobol' method is used to improve our understanding of the effect of parameter groups on crop production under various irrigation schemes. The results are shown in Table 7. In the above mentioned irrigation-water scenarios, summations of first-order indices of parameters are always close to 1 , which suggests that the coupled model has not overparameterization. Total-order indices of parameters are not significantly different in the coupled model, which may be attributed to the coupled model as being balance. Summation of total-order indices leads to values between $2.65 \neg 3.8$, suggesting that the simulated yield is always affected by more parameters acting in conjunction with each other. Table 7 reveals that the crop outputs are mainly influenced by physiological parameters (including $\mathrm{CO}_{2}$ assimilation, green area, correction factor transpiration rate, the conversion of assimilates into the various organs compounds) and environment parameters (including sowing date, groundwater depth, soil hydraulic characteristic). Table 7 further shows that the effect of groundwater, soil hydraulic characteristic and correction factor transpiration rate on output increases as irrigationwater decreases. The effect of most physiological parameters on output decreases as irrigation-water decreases, owing to the fact that a shortage of transpiration supplied water uptake from the soil causes stomata closure and reduces assimilation and respiration of crops. These results demonstrate the water limitation is the major factor to maize yield in arid region.

\section{Summary and conclusions}

The objective of this study is to develop a fully coupled hydrology-crop growth model which can optimize irrigation-water under different climatic and environmental conditions. A crop growth model (WOFOST) has been coupled to a hydrologic model (HYDRUS) for this purpose. The coupled model considers not only the physiological processes of the crop, but also the water balance during the crop growth process.

The coupled model is calibrated using field data collected at an experimental field in the middle reaches of northwest China's Heihe River, located in a semi-arid to arid region. 
Table 3. The output variables of maize growth obtained by the coupled model.

\begin{tabular}{|c|c|c|c|c|c|c|c|c|}
\hline DOY & TAGP & TWLV & TWST & TWSO & TWRT & LAI & $\mathrm{HI}$ & GASS \\
\hline $\begin{array}{l}\text { Day of } \\
\text { year }\end{array}$ & $\begin{array}{r}\text { Total } \\
\text { above } \\
\text { ground } \\
\text { production }\end{array}$ & $\begin{array}{l}\text { Total dry } \\
\text { weight of } \\
\text { the leaves }\end{array}$ & $\begin{array}{l}\text { Total dry } \\
\text { weight of } \\
\text { the stems }\end{array}$ & $\begin{array}{r}\text { Total dry } \\
\text { weight of } \\
\text { storage } \\
\text { organs }\end{array}$ & $\begin{array}{l}\text { Total dry } \\
\text { weight of } \\
\text { the roots }\end{array}$ & $\begin{array}{l}\text { Leaf } \\
\text { area } \\
\text { index }\end{array}$ & $\begin{array}{l}\text { Harvest } \\
\text { index }\end{array}$ & $\begin{array}{l}\text { Gross } \\
\text { assimilation } \\
\text { rate }\end{array}$ \\
\hline- & $\mathrm{kg} \mathrm{ha}^{-1}$ & $\mathrm{~kg} \mathrm{ha}^{-1}$ & $\mathrm{~kg} \mathrm{ha}^{-1}$ & $\mathrm{~kg} \mathrm{ha}^{-1}$ & $\mathrm{~kg} \mathrm{ha}^{-1}$ & $\mathrm{~m}^{2} \mathrm{~m}^{2}$ & - & $\mathrm{kg} \mathrm{ha}^{-1} \mathrm{~d}^{-1}$ \\
\hline 124 & 30 & 19 & 11 & 0 & 20 & 0.05 & 0 & 2.4 \\
\hline 129 & 62 & 39 & 24 & 0 & 40 & 0.08 & 0 & 30.6 \\
\hline 134 & 102 & 63 & 39 & 0 & 64 & 0.11 & 0 & 19.8 \\
\hline 139 & 134 & 83 & 51 & 0 & 82 & 0.16 & 0 & 29.9 \\
\hline 144 & 230 & 143 & 87 & 0 & 132 & 0.28 & 0 & 103.1 \\
\hline 149 & 503 & 312 & 191 & 0 & 264 & 0.61 & 0 & 227.8 \\
\hline 154 & 1197 & 741 & 456 & 0 & 566 & 0.93 & 0 & 284.4 \\
\hline 159 & 2165 & 1291 & 875 & 0 & 931 & 1.31 & 0 & 608 \\
\hline 164 & 3587 & 2016 & 1570 & 0 & 1397 & 1.78 & 0 & 577.9 \\
\hline 169 & 4055 & 2231 & 1824 & 0 & 1531 & 2.33 & 0 & 101.6 \\
\hline 174 & 5476 & 2737 & 2739 & 0 & 1831 & 2.92 & 0 & 649.7 \\
\hline 179 & 6759 & 3108 & 3651 & 0 & 2042 & 3.67 & 0 & 635.2 \\
\hline 184 & 8080 & 3378 & 4702 & 0 & 2179 & 4.87 & 0 & 205.9 \\
\hline 189 & 8877 & 3497 & 5380 & 0 & 2223 & 5.31 & 0 & 651.7 \\
\hline 194 & 10081 & 3662 & 6256 & 164 & 2233 & 5.29 & 0.02 & 265.4 \\
\hline 199 & 10218 & 3677 & 6325 & 217 & 2233 & 4.81 & 0.02 & 220.5 \\
\hline 204 & 11385 & 3709 & 6457 & 1219 & 2233 & 4.64 & 0.11 & 661 \\
\hline 209 & 12724 & 3709 & 6457 & 2558 & 2233 & 4.38 & 0.20 & 605.1 \\
\hline 214 & 13674 & 3709 & 6457 & 3508 & 2233 & 4.27 & 0.26 & 93.5 \\
\hline 219 & 14852 & 3709 & 6457 & 4686 & 2233 & 4.06 & 0.32 & 436.2 \\
\hline 224 & 15874 & 3709 & 6457 & 5708 & 2233 & 4.04 & 0.36 & 314.2 \\
\hline 229 & 16139 & 3709 & 6457 & 5973 & 2233 & 3.74 & 0.37 & 175 \\
\hline 234 & 17169 & 3709 & 6457 & 7003 & 2233 & 3.65 & 0.41 & 512.5 \\
\hline 239 & 18103 & 3709 & 6457 & 7937 & 2233 & 3.57 & 0.44 & 483.5 \\
\hline 244 & 19112 & 3709 & 6457 & 8946 & 2233 & 3.43 & 0.47 & 167.1 \\
\hline 249 & 19612 & 3709 & 6457 & 9446 & 2233 & 2.95 & 0.48 & 80.3 \\
\hline 254 & 20013 & 3709 & 6457 & 9847 & 2233 & 2.68 & 0.49 & 124.1 \\
\hline 259 & 20498 & 3709 & 6457 & 10332 & 2233 & 2.1 & 0.50 & 219.3 \\
\hline 261 & 20743 & 3709 & 6457 & 10577 & 2233 & 1.89 & 0.51 & 206.4 \\
\hline
\end{tabular}

Table 4. The simulated water balance under actual and guided irrigation schemes.

\begin{tabular}{lllcrr}
\hline & $\begin{array}{l}\text { Irrigation }+ \\
\text { precipitation }\end{array}$ & Transpiration & Evaporation & $\begin{array}{r}\text { Deep } \\
\text { percolation }\end{array}$ & $\begin{array}{r}\text { Change of } \\
\text { soil moisture } \\
\text { storage }\end{array}$ \\
\hline & & & $\mathrm{mm}$ & & \\
\cline { 2 - 6 } & 983.6 & 364 & 203 & 344.6 & 72 \\
Realistic irrigation scheme & 633.6 & 355 & 151 & 60.4 & 67.2 \\
Guided irrigation scheme & -350 & -9 & -52 & -284.2 & -4.8 \\
Difference & & &
\end{tabular}

The results show the good agreement is achieved between coupled model simulations and field measurements under water limited-conditions. The results also show that the coupled model can have a higher precision than the WOFOST model alone owing to HYDRUS model's advantage in simulating soil moisture and root water uptake as a physical process. Based on the coupled model, the scenario analysis results indicate that the most optimal irrigation amount for maize growth is $500-600 \mathrm{~mm}$ in this region. These applications illustrate the coupled model can be used for analysis of saving-water approach and also for the study on interaction between crop growth and the hydrological cycle. 
Table 5. The groups of parameters and the value ranges of parameters for UA/SA.

\begin{tabular}{|c|c|c|c|c|}
\hline group & parameter & meaning & unit & values range \\
\hline Sowing date & IDSOW & sowing date & (d) & $\mathrm{U}(103-117)$ \\
\hline $\begin{array}{l}\text { Groundwater } \\
\text { depth }\end{array}$ & ZIT & Initial depth of groundwater table & $(\mathrm{cm})$ & $\mathrm{U}(50-500)$ \\
\hline $\begin{array}{l}\text { Soil } \\
\text { hydraulic } \\
\text { parameters } \\
\text { (HYDRUS) }\end{array}$ & $\begin{array}{l}\text { Parameters } \\
\text { of } \\
\text { HYDRUS } \\
\text { model }\end{array}$ & soil hydraulic parameters & $\begin{array}{l}\left(\mathrm{cm} \mathrm{cm}^{-1}\right) \\
\left(\mathrm{cm} \mathrm{cm}^{-1}\right) \\
- \\
- \\
\left(\mathrm{cm} \mathrm{day}^{-1}\right)\end{array}$ & $\begin{array}{l}\theta_{\mathrm{r}} \mathrm{U}(0.01-0.1) \\
\theta_{\mathrm{S}} \mathrm{U}(0.25-0.4) \\
a \mathrm{U}(0.02-0.14) \\
n \mathrm{U}(0.2-0.6) \\
K_{\mathrm{S}} \mathrm{U}(10-800)\end{array}$ \\
\hline Emergence & $\begin{array}{l}\text { TBASEM } \\
\text { TEFFMX }\end{array}$ & $\begin{array}{l}\text { Lower threshold temperature for emergence } \\
\text { Maximum effective temperature for emergence }\end{array}$ & $\begin{array}{l}\left({ }^{\circ} \mathrm{C}\right) \\
\left({ }^{\circ} \mathrm{C}\right)\end{array}$ & $\begin{array}{l}\mathrm{U}(2-5) \\
\mathrm{U}(20-30)\end{array}$ \\
\hline Phenology & $\begin{array}{l}\text { TSUM1 } \\
\text { TSUM2 }\end{array}$ & $\begin{array}{l}\text { Thermal time from emergence to anthesis } \\
\text { Thermal time from anthesis to maturity }\end{array}$ & $\begin{array}{l}\left({ }^{\circ} \mathrm{Cd}^{-1}\right) \\
\left({ }^{\circ} \mathrm{Cd}^{-1}\right)\end{array}$ & $\begin{array}{l}\mathrm{U}(700-900) \\
\mathrm{U}(800-1200)\end{array}$ \\
\hline Initial & $\begin{array}{l}\text { RGRLAI } \\
\text { LAIEM }\end{array}$ & $\begin{array}{l}\text { Maximum relative increase in LAI } \\
\text { Leaf area index at emergence }\end{array}$ & $\begin{array}{l}(\text { ha ha } \\
\text { (ha ha } \\
\text { (h) }\end{array}$ & $\begin{array}{l}\mathrm{U}(0.01-0.04) \\
\mathrm{U}(0.1-0.2)\end{array}$ \\
\hline Green area & $\begin{array}{l}\text { SPAN } \\
\text { SLATB } \\
\text { SLATB1 }\end{array}$ & $\begin{array}{l}\text { Life span of leaves growing at } 35^{\circ} \mathrm{C} \\
\text { Specific leaf area as a function of development stage } \\
\text { Specific leaf area as a function of development stage }\end{array}$ & $\begin{array}{l}\text { (d) } \\
(\text { ha kg-1) } \\
(\text { ha kg-1) }\end{array}$ & $\begin{array}{l}\mathrm{U}(30-36) \\
\mathrm{U}(0.002-0.003) \\
\mathrm{U}(0.001-0.002)\end{array}$ \\
\hline \multirow[t]{7}{*}{ Assimilation } & AMAXTB & $\begin{array}{l}\text { Maximum leaf } \mathrm{CO}_{2} \text { assimilation rate at development } \\
\text { stage of the crop growth }\end{array}$ & $\left(\mathrm{kg} \mathrm{ha}^{-1} \mathrm{~h}^{-1}\right)$ & $\mathrm{U}(50-70)$ \\
\hline & AMAXTB1 & $\begin{array}{l}\text { Maximum leaf } \mathrm{CO}_{2} \text { assimilation rate at the first } \\
\text { development stage of the crop maturity }\end{array}$ & $\left(\mathrm{kg} \mathrm{ha}^{-1} \mathrm{~h}^{-1}\right)$ & $\mathrm{U}(50-70)$ \\
\hline & AMAXTB2 & $\begin{array}{l}\text { Maximum leaf } \mathrm{CO}_{2} \text { assimilation rate at the second } \\
\text { development stage of the crop maturity }\end{array}$ & $\left(\mathrm{kg} \mathrm{ha}^{-1} \mathrm{~h}^{-1}\right)$ & $\mathrm{U}(50-70)$ \\
\hline & AMAXTB3 & $\begin{array}{l}\text { Maximum leaf } \mathrm{CO}_{2} \text { assimilation rate at the third } \\
\text { development stage of the crop maturity }\end{array}$ & $\left(\mathrm{kg} \mathrm{ha}^{-1} \mathrm{~h}^{-1}\right)$ & $\mathrm{U}(30-50)$ \\
\hline & AMAXTB4 & $\begin{array}{l}\text { Maximum leaf } \mathrm{CO}_{2} \text { assimilation rate at the fourth } \\
\text { development stage of the crop maturity }\end{array}$ & $\left(\mathrm{kg} \mathrm{ha}^{-1} \mathrm{~h}^{-1}\right)$ & $\mathrm{U}(0-25)$ \\
\hline & EFFTB & $\begin{array}{l}\text { Initial light-use efficiency of } \mathrm{CO}_{2} \text { assimilation } \\
\text { of single leaves as function of daily temperature }\end{array}$ & $\begin{array}{l}\left(\left(\mathrm{kg} \mathrm{ha}^{-1}\right.\right. \\
\left.\mathrm{h}^{-1}\right) /\left(\mathrm{Jm}^{-2}\right. \\
\left.\left.\mathrm{s}^{-1}\right) ;{ }^{\circ} \mathrm{C}\right)\end{array}$ & $\mathrm{U}(0.4-0.5)$ \\
\hline & KDIFTB & $\begin{array}{l}\text { Extinction coefficient for diffuse visible light } \\
\text { as function of development stage }\end{array}$ & & $\mathrm{U}(0.5-0.7)$ \\
\hline $\begin{array}{l}\text { Conversion } \\
\text { of } \\
\text { assimilates } \\
\text { into } \\
\text { biomass }\end{array}$ & $\begin{array}{l}\text { CVO } \\
\text { CVS } \\
\text { CVL } \\
\text { CVR }\end{array}$ & $\begin{array}{l}\text { Conversion efficiency of assimilates into storage organ } \\
\text { Conversion efficiency of assimilates into stem } \\
\text { Conversion efficiency of assimilates into leaf } \\
\text { Conversion efficiency of assimilates into root }\end{array}$ & $\begin{array}{l}\left(\mathrm{kg} \mathrm{kg}^{-1}\right) \\
\left(\mathrm{kg} \mathrm{kg}^{-1}\right) \\
\left(\mathrm{kg} \mathrm{kg}^{-1}\right)\end{array}$ & $\begin{array}{l}\mathrm{U}(0.6-0.8) \\
\mathrm{U}(0.59-0.76) \\
\mathrm{U}(0.61-0.75) \\
\mathrm{U}(0.62-0.76)\end{array}$ \\
\hline \multirow[t]{2}{*}{$\begin{array}{l}\text { Maintenance } \\
\text { respiration }\end{array}$} & $\begin{array}{l}\text { RMS } \\
\text { RML } \\
\text { Q10 }\end{array}$ & $\begin{array}{l}\text { Relative maintenance respiration rate stems } \\
\text { Relative maintenance respiration rate leaves } \\
\text { Relative change in respiration rate per } 10^{\circ} \mathrm{C} \\
\text { temperature change }\end{array}$ & $\begin{array}{l}\left(\mathrm{kg}\left(\mathrm{CH}_{2} \mathrm{O}\right) \mathrm{kg}^{-1} \mathrm{~d}^{-1}\right) \\
\left(\mathrm{kg}\left(\mathrm{CH}_{2} \mathrm{O}\right) \mathrm{kg}^{-1} \mathrm{~d}^{-1}\right)\end{array}$ & $\begin{array}{l}\mathrm{U}(0.013-0.02) \\
\mathrm{U}(0.027-0.033) \\
\mathrm{U}(1.6-2)\end{array}$ \\
\hline & $\begin{array}{l}\text { RMO } \\
\text { RMR }\end{array}$ & $\begin{array}{l}\text { Relative maintenance respiration rate storage organs } \\
\text { Relative maintenance respiration rate roots }\end{array}$ & $\begin{array}{l}\left(\mathrm{kg}\left(\mathrm{CH}_{2} \mathrm{O}\right) \mathrm{kg}^{-1} \mathrm{~d}^{-1}\right) \\
\left(\mathrm{kg}\left(\mathrm{CH}_{2} \mathrm{O}\right) \mathrm{kg}^{-1} \mathrm{~d}^{-1}\right)\end{array}$ & $\begin{array}{l}\mathrm{U}(0.005-0.015) \\
\mathrm{U}(0.01-0.016)\end{array}$ \\
\hline $\begin{array}{l}\text { Death rates } \\
\text { due to water } \\
\text { stress }\end{array}$ & PERDL & $\begin{array}{l}\text { Maximum relative death rate of leaves due to water } \\
\text { stress }\end{array}$ & $\left(\mathrm{kg} \mathrm{kg}^{-1} \mathrm{~d}^{-1}\right)$ & $\mathrm{U}(0.02-0.06)$ \\
\hline $\begin{array}{l}\text { Correction } \\
\text { factor } \\
\text { transpiration } \\
\text { rate }\end{array}$ & CFET & correction factor transpiration rate & & $\mathrm{U}(0.7-1.2)$ \\
\hline $\begin{array}{l}\text { Root } \\
\text { parameters }\end{array}$ & $\begin{array}{l}\text { RRI } \\
\text { RDI } \\
\text { RDMCR }\end{array}$ & $\begin{array}{l}\text { Maximum daily increase in rooting depth } \\
\text { Initial rooting depth } \\
\text { maximum rooting depth }\end{array}$ & $\begin{array}{l}\left(\mathrm{cm} \mathrm{d}^{-1}\right) \\
(\mathrm{cm}) \\
(\mathrm{cm})\end{array}$ & $\begin{array}{l}\mathrm{U}(2-3) \\
\mathrm{U}(7-14) \\
\mathrm{U}(90.5-120)\end{array}$ \\
\hline
\end{tabular}


Table 6. The Morris sensitivity measures $\mu^{*}$ and $\sigma$ for 13 groups of parameters.

\begin{tabular}{|c|c|c|c|c|c|}
\hline parameter & $\mu^{*}$ & $\sigma$ & parameter & $\mu^{*}$ & $\sigma$ \\
\hline $\begin{array}{l}\text { Soil characteristics } \\
\text { (parameters of HYDRUS) }\end{array}$ & 10731 & 6411.7 & Q10 & 639 & 297.5 \\
\hline ZIT & 6053 & 5172.5 & TSUM2 & 562 & 359.6 \\
\hline SLATB1 & 3375 & 2650.9 & CVS & 562 & 598.6 \\
\hline IDSOW & 3306 & 2304.1 & PERDL & 441 & 688.8 \\
\hline EFFTB & 2970 & 1723.4 & RMO & 419 & 221.1 \\
\hline RDMCR & 2775 & 3062 & RMS & 410 & 119.1 \\
\hline KDIFTB & 2455 & 1389.9 & RML & 394 & 363.2 \\
\hline CFET & 2127 & 2008.6 & АМАХТВ & 351 & 326.1 \\
\hline CVL & 1464 & 2801.4 & AMAXTB1 & 343 & 159.7 \\
\hline SLATB & 1458 & 1498.6 & AMAXTB2 & 338 & 136.8 \\
\hline $\mathrm{CVO}$ & 1452 & 745.1 & AMAXTB3 & 268 & 212.4 \\
\hline RDI & 1427 & 1505 & AMAXTB4 & 232 & 82.9 \\
\hline TSUM1 & 1387 & 1245 & SPAN & 180 & 278.6 \\
\hline TBASEM & 1385 & 1068.1 & RMR & 162 & 36.4 \\
\hline RRI & 845 & 683.3 & TEFFMX & 0 & 0 \\
\hline CVR & 802 & 815.4 & LAIEM & 0 & 0 \\
\hline RGRLAI & 667 & 837.4 & & & \\
\hline
\end{tabular}

Table 7. First effect and total effect indices of 13 groups of parameters.

\begin{tabular}{|c|c|c|c|c|c|c|c|c|}
\hline \multirow[b]{2}{*}{ Group of parameters } & \multicolumn{2}{|c|}{ Irrigation $100 \mathrm{~mm}$} & \multicolumn{2}{|c|}{ Irrigation $80 \mathrm{~mm}$} & \multicolumn{2}{|c|}{ Irrigation $60 \mathrm{~mm}$} & \multicolumn{2}{|c|}{ Irrigation $40 \mathrm{~mm}$} \\
\hline & first & total & first & total & first & total & first & total \\
\hline sowing date & 0.1057 & 0.2686 & 0.0982 & 0.2228 & 0.1002 & 0.1887 & 0.0731 & 0.1376 \\
\hline groundwater depth & 0.0817 & 0.2601 & 0.1257 & 0.3466 & 0.2588 & 0.4384 & 0.3469 & 0.651 \\
\hline Soil hydraulic parameters (HYDRUS) & 0.1355 & 0.2805 & 0.1446 & 0.2997 & 0.1846 & 0.3627 & 0.2561 & 0.4034 \\
\hline emergence & 0.0385 & 0.1383 & 0.0345 & 0.1843 & 0.0385 & 0.1956 & 0.0307 & 0.1246 \\
\hline phenology & 0.0335 & 0.103 & 0.0276 & 0.1171 & 0.0195 & 0.1224 & 0.0056 & 0.1136 \\
\hline initial & 0.0432 & 0.3609 & 0.0398 & 0.3541 & 0.0273 & 0.1161 & 0.027 & 0.0809 \\
\hline green area & 0.0965 & 0.3596 & 0.0566 & 0.263 & 0.0247 & 0.1691 & 0.0054 & 0.0913 \\
\hline assimilation & 0.1474 & 0.5965 & 0.1446 & 0.6634 & 0.0958 & 0.3577 & 0.0416 & 0.1421 \\
\hline conversion of assimilates into biomass & 0.093 & 0.36 & 0.1023 & 0.3113 & 0.0642 & 0.2049 & 0.0144 & 0.1556 \\
\hline maintenance respiration & 0.0441 & 0.2523 & 0.0407 & 0.306 & 0.0277 & 0.266 & 0.0193 & 0.1618 \\
\hline death rates due to water stress & 0.0112 & 0.1429 & 0.0042 & 0.2882 & 0.0048 & 0.1632 & 0.0083 & 0.0924 \\
\hline correction factor transpiration rate & 0.0907 & 0.2563 & 0.0764 & 0.2858 & 0.088 & 0.3538 & 0.096 & 0.404 \\
\hline root parameters & 0.0569 & 0.2057 & 0.0382 & 0.1615 & 0.0293 & 0.1885 & 0.0164 & 0.0981 \\
\hline Total & 0.9779 & 3.5847 & 0.9334 & 3.8038 & 0.9634 & 3.1271 & 0.9408 & 2.6564 \\
\hline
\end{tabular}

Uncertainty and sensitivity analysis methods are used to evaluate the coupled model, to predict maize production, and to study effect of crop parameters and environmental factors on maize production. The study results indicate that the uncertainty analysis using Monte Carlo method can reveal the risk of a possible loss of crop production with irrigation decrease and provide the probability of crop production in the uncertainty range of crop parameters and environment parameters. The sensitivity analysis reveals the effect of coupled model parameters and environment scenarios on maize production. This developed method can be used for crop production estimation in a region with limited available data. Synthetically, the method of integrating a coupled hydrologic and crop growth model with uncertainty analysis and sensitivity analysis can be used for guiding agricultural irrigation, saving water resources, predicting agricultural production and researching effects of the climatic and environmental change on agricultural production.

Acknowledgements. This work is supported the NSFC (National Science Foundation of China) project (grant number: 40901020) and the CAS (Chinese Academy of Sciences) knowledge innovation project (grant number: KZCX2-YW-Q10-1). Gratitude is expressed to Yingke experimental station for collecting data and working. Thanks for the reviewers' and the editor's thoughtful comments and constructive suggestions.

Edited by: A. Shamseldin 


\section{References}

Anwar, M. R., McKenzie, B. A., and Hill, G. D.: Water-use efficiency and the effect of water deficits on crop growth and yield of kabuli chickpea (Cicer arietinum L.) in a cool-temperate subhumid climate, J. Agric. Sci., 141, 285-301, 2003.

Berge, H. F. M., Aggarwal, P. K., and Kropff, M. J. (Eds.): Applications of Rice Modelling, Elsevier, The Netherlands, 166 pp., 1997.

Boogaard, H. L., Van Diepen, C. A., Rötter, R. P., Cabrera, J. C. M. A., and Van Laar, H. H.: WOFOST 7.1: User's Guide for the WOFOST 7.1 Crop Growth Simulation Model and WOFOST Control Center 1.5, Techn. Doc. 52, Alterra, WUR, Wageningen, The Netherlands, 144 pp., 1998.

Boons-Prins, E. R., de Koning, G. H. J., Van Diepen, C. A., and Penning de Vries, F. W. T.: Crop specific simulation parameters for yield forecasting across the European Community, Simulation Reports CABO-TT 32, CABO-DLO, DLO Winand Staring Centre, JRC, Wageningen, 1993.

Bouman, B. A. M., Kropff, M. J., Tuong, T. P., Wopereis, M. C. S., Ten Berge, H. F. M., and Van Laar, H. H.: ORYZA2000: modeling lowland rice, IRRI/Wageningen University, Wageningen, 2001.

Brisson, N., Gary, C., Justes, E., Roche, R., Mary, B., Ripoche, D., Zimmer, D., Sierra, J., Bertuzzi, P., Burger, P., Bussiere, F., Cabidoche, Y. M., Cellier, P., Debaeke, P., Gaudillere, J. P., Henault, C., Maraux, F., Seguin, B., and Sinoquet, H.: An overview of the crop model, Eur. J. Agron., 18, 309-332, 2003.

Burman, R. and Pochop, L. O.: Evaporation, evapotranspiration and climatic data, in: Developments in Atmospheric Science, vol. 22, Elsevier, Amsterdam, The Netherlands, 278 pp., 1994.

Campbell, G. S. and Norman, J. M.: An Introduction to Environmental Biophysics, 2nd Edn., Springer-Verlag, New York, 1998.

Chen, C., Wang, E. L., and Yu, Q.: Modelling the effects of climate variability and water management on crop water productivity and water balance in the North China Plain, Agr. Water Manage., 97, 1175-1184, 2010.

David, G.: Hazy Reasoning Behind Clean Air: science alone can't determine how regulations are written, Nature, 452, 519, doi:10.1038/452519a, 2008.

De Willigen, P.: Nitrogen turnover in the soil crop system: comparison of fourteen simulation models, Fertilizer Res., 27, 141-149, 1991.

Diekkrüger, B., Söndgerath, D., Kersebaum, K. C., and McVoy, C. W.: Validity of agroecosystem models a comparison of results of different models applied to the same data set, Ecol. Modell., 81, 3-29, 1995.

Eitzinger, J., Trnka, M., Hösch, J., Zalud, Z., and Dubrovsky', M.: Comparison of CERES, WOFOST and SWAP models in simulating soil water content during growing season under different soil conditions, Ecol. Modell., 171, 223-246, 2004.

Engel, Th. and Priesack, E.: Expert-N, a building block system of nitrogen models as resource for advice, research, water management and policy, in: Integrated Soil and Sediment Research: A Basis for Proper Protection, edited by: Eijsackers, H. J. P. and Hamers, T., Kluwer Academic Publishers, Dordrecht, The Netherlands, 503-507, 1993.
Fang, Q., Ma, L., Yu, Q., Ahuja, L. R., Malone, R. W., and Hoogenboom, G.: Irrigation strategies to improve the water use efficiency of wheat-maize double cropping systems in North China Plain, Agr. Water Manage., 97, 1165-1174, 2010.

Feddes, R. A., Kowalik, P. J., and Zaradny, H.: Simulation of field water use and crop yield, Simulation Monograph, Pudoc, Wageningen, The Netherlands, 9-30, 1978.

Fox, G. A., Muñoz-Carpena, R., and Sabbagh, G. J.: Influence of flow concentration on parameter importance and prediction uncertainty of pesticide trapping by vegetative filter strips, J. Hydrol., 384, 164-173, 2010.

Gartuza-Payán, J., Shuttleworth, W. J., Encinas, D., McNeil, D. D., Stewart, J. B., DeBruin, H., and Watts, C.: Measurement and modelling evaporation for irrigated crops in northwest Mexico, Hydrol. Process., 12, 1397-1418, 1998.

Gee, G. W. and Or, D.: Particle size analysis, in: Methods of Soil Analysis, Part 4, SSSA Book Series, vol. 5, edited by: Dane, J. and Topp, C., American Society of Agronomy, Madison, Wisconsin, 255-294, 2002.

Grossman, R. B. and Reinsch, T. G.: Bulk density and linear extensibility, in: Methods of Soil Analysis, Part 4, SSSA Book Series, vol. 5. edited by: Dane, J. and Topp, C., American Society of Agronomy, Madison, Wisconsin, 201-228, 2002.

Hornberger, G. M. and Spear, R. C.: An approach to the preliminary analysis of environmental systems, J. Environ. Manage., 12, 7$18,1981$.

Ines, A. V. M., Gupta, A. D., and Loof, R.: Application of GIS and crop growth models in estimating water productivity, Agr. Water Manage., 54, 205-225, 2002.

Jawitz, J. W., Muñoz-Carpena, R., Muller, S., Grace, K. A., and James, A. I.: Development, Testing, and Sensitivity and Uncertainty Analyses of a Transport and Reaction Simulation Engine (TaRSE) for Spatially Distributed Modeling of Phosphorus in South Florida Peat Marsh Wetlands: U.S. Geological Survey Scientific Investigations Report 2008-5029, http://pubs.usgs.gov/sir/ 2008/5029/, last access: May 2012, 109 pp., 2008.

Jiang, J., Feng, S. Y., Huo, Z. L., Zhao, Z. C., and Jia, B.: Application of the SWAP model to simulate water-salt transport under deficit irrigation with saline water, Math. Comput. Modell., 54, 902-911, 2011.

Jones, J. W., Keating, B. A., and Porter, C. H.: Approaches to modular model development, Agric. Syst., 70, 421-443, 2001.

Jones, J. W., Hoogenboom, G., Porter, C. H., Boote, K .J., Batchelor, W. D., Hunt, L. A., Wilkens, P. W., Singh, U., Gijsman, A. J., and Ritchie, J. T.: The DSSAT cropping system model, Eur. J. Agron., 18, 235-265, 2003.

Keating, B. A., Carberry, P. S., Hammer, G. L., Probert, M. E., Robertson, M. J., Holzworth, D., Huth, N. I., Hargreaves, J. N. G., Meinke, H., Hochman, Z., McLean, G., Verburg, K., Snow, V., Dimes, J. P., Silburn, M., Wang, E., Brown, S., Bristow, K. L., Asseng, S., Chapman, S., McCown, R. L., Freebairn, D. M., and Smith, C. J.: An overview of APSIM, a model designed for farming systems simulation, Eur. J. Agron., 18, 267-288, 2003.

Kendy, E., Gérard-Marchant, P., Walter, M. T., Zhang, Y., Liu, C., and Steenhuis, T. S.: A soil-water-balance approach to quantify groundwater recharge from irrigated cropland in the North China Plain, Hydrol. Process., 17, 2011-2031, 2003. 
Kroes, J. G., Van Dam, J. C., Groenendijk, P., Hendriks, R. F. A., and Jacobs, C. M. J.: SWAP version 3.2: Theory description and user manual, Report 1649, Alterra, Wageningen, 262 pp., 2008.

Kropff, M. J., Teng, P. S., Aggarwal, P. K., Bouman, B., Bouma, J., and Van Laar, H. H.: Applications of Systems Approaches at the Field Level, vol. 2, Kluwer Academic Publishers, The Netherlands, 465 pp., 1996.

Lomborg, B.: The Skeptical Environmentalist: Measuring the Real State of the World, Cambridge University Press, New York, 2001.

Matthews, R. B. and Stephens, W.: Crop-soil Simulation Models, Applications in Developing Countries, CABI Publishing, Wallingford, UK, 277 pp., 2002.

McKay, M. D.: Evaluating Prediction Uncertainty. NUREG/CR6311, US Nuclear Regulatory Commission and Los Alamos National Laboratory, Los Alamos, N. M., 1995.

Molden, D.: Accounting for Water Use and Productivity, SWIM Paper 1, International Irrigation Management Institute, Colombo, Sri Lanka, 1997.

Monteith, J. L.: Evaporation and environment, in: Proceedings of the 19th Symposium of the Society for Experimental Biology, Cambridge University Press, New York, 205-233, 1965.

Monteith, J. L.: Evaporation and surface temperature, Q. J. Roy. Meteorol. Soc., 107, 1-27, 1981.

Monteith, J. L. and Unsworth, M. H.: Principles of environmental physics, 2nd Edn., Edwad Arnold, London, UK, 1990.

Morris, M.: Factorial sampling plans for preliminary computational experiments, Technometrics, 33, 161-174, 1991.

Mualem, Y.: A new model predicting the hydraulic conductivity of unsaturated porous media, Water Resour. Res., 12, 513-522, 1976.

Muñoz-Carpena, R., Fox, G. A., and Sabbagh, G. J.: Parameter importance and uncertainty in predicting runoff pesticide reduction with filter strips, J. Environ. Qual., 39, 1-12, 2010.

Patil, S. L. and Sheelavantar, M. N.: Effect of cultural practices on soil properties, moisture conservation and grain yield of winter sorghum in semi-arid tropics of India, Hydrol. Process., 64, 4967, 2004.

Paudyal, G. N. and Das Gupta, A.: Irrigation planning by multi-level optimization, J. Irrig. Drain. Eng.-ASCE, 116, 273-291, 1990.

Pilkey, O. H. and Pilkey-Jarvis, L.: Useless arithmetic: Why Environmental Scientists Can't Predict the Future, Columbia University Press, New York, 2007.

Priesack, E.: Expert-N Dokumentation der Modell-Bibliothek, FAM Bericht 60, Hieronymus, München, 2006.

Priesack, E., Gayler, S., and Hartmann, H. P.: The impact of crop growth sub-model choice on simulated water and nitrogen balances, Nutr. Cycl. Agroecosys., 75, 1-13, 2006.

Raman, H., Mohan, S., and Rangacharya, N. C. V.: Decision support for crop planning during droughts, J. Irrig. Drain. Eng.-ASCE, 118, 229-241, 1992.

Rodriguez-Iturbe, I., Porporato, A., Laio, F., and Ridolfi, L.: Intensive or extensive use of soil moisture: plant strategies to cope with stochastic water availability, Geophys. Res. Lett., 28, 44954497, 2001.

Saltelli, A.: Making best use of model evaluations to compute sensitivity indices, Comput. Phys. Commun., 145, 280-297, 2002.
Saltelli, A., Tarantola, S., Campolongo, F., and Ratto, M.: Sensitivity Analysis in practice, A Guide to Assessing Scientific Models, John Wiley \& Sons, Joint Research Centre of the European Commission, Ispra, Italy, 2004.

Scanlon, B. R., Healy, R. W., and Cook, P. G.: Choosing appropriate techniques for quantifying groundwater recharge, Hydrogeol. J., 10, 18-39, 2002.

Schaap, M. G. and Bouten, W.: Modeling water retention curves of sandy soils using neural networks, Water Resour. Res., 32, 30333040, 1996.

Schaap, M. G., Leij, F. J., and van Genuchten M. Th.: Neural network analysis for hierarchical prediction of soil water retention and saturated hydraulic conductivity, Soil Sci. Soc. Am. J., 62, 847-855, 1998.

Seckler, D., Amerasinghe, U., Molden, D., De Silva, R., and Barker, R.: World Water Demand and Supply, 1990 to 2025: Scenarios and Issues, Research Report 19, IWMI, Colombo, Sri Lanka, 1998.

Shaffer, M. J., Ma, L., and Hansen, S.: Modeling Carbon and Nitrogen Dynamics for Soil Management, Lewis Publishers, Boca Raton, FL, USA, 2001.

Shepherd, A., McGinn, S. M., and Wyseure, G. C. L.: Simulation of the effect of water shortage on the yields of winter wheat in north-east England, Ecol. Modell., 147, 41-52, 2002.

Šimůnek, J., Van Genuchten, M. Th., and Šejna, M.: The HYDRUS1D Software Package for Simulating the Movement of Water, Heat, and Multiple Solutes in Variability Saturated Media, Version 3.0, Department of Environmental Sciences University of California Riverside, Riverside, California, USA, 270 pp., 2005.

Smettem, K. R. J.: Editorial-welcome address for the new 'Ecohydrology', Journal, Ecohydrology, 1, 1-2, 2008.

Sobol, I. M.: Sensitivity estimates for nonlinear mathematical models, Math. Modell. Comput. Exp., 1, 407-414, 1993.

Sperr, C., Engel, T., and Priesack, E.: Expert-N, Aufbau, Bedienung und Nutzungsmöglichkeiten des Prototyps, in: Expert$\mathrm{N}$ und Wachstumsmodelle. Referate des Anwenderseminars im März 1993 in Weihenstephan, Agrarinformatik 24, edited by: Engel, T. and Baldioli, M., Verlag Eugen Ulmer, Stuttgart, 41-57, 1993.

Stokstad, E.: Agriculture: dueling visions for a hungry world, Science, 319, 1474-1476, doi:10.1126/science.319.5869.1474, 2008.

Tsuji, G. Y., Hoogenboom, G., and Thornton, P. K.: Understanding Options for Agricultural Production, Kluwer Academic Publishers, The Netherlands, p. 399, 1998.

Tuong, T. P. and Bhuiyan, S. I.: Increasing water-use efficiency in rice production: farm-level perspectives, Agr. Water Manage., 40, 117-122, 1999.

Van der Sluijs, J. P.: A way out of the credibility crisis of models used in integrated environmental assessment, Futures, 34, 133146, 2002.

Van Genuchten, M. Th.: A closed-form equation for predicting the hydraulic conductivity of unsaturated soils, Soil Sci. Soc. Am. J., 44, 892-898, 1980.

Van Ittersum, M. K. and Donatelli, M.: Modelling cropping systems - highlights of the symposium and preface to the special issues, Eur. J. Agron., 18, 187-197, 2003. 
Van Keulen, H. and Wolf, J.: Modelling of agricultural production: Weather soils and crops, in: Simulation Monographs, Pudoc, Wageningen, The Netherlands, 479 pp., 1986.

Van Laar, H. H., Goudriaan, J., and Van Keulen, H.: SUCROS 97: Simulation of crop growth for potential and water-limited production situations, as applied to spring wheat, Quantitative Approaches in Systems Analysis, vol. 14, AB-DLO, Wageningen, The Netherlands. 1997.

Veld, R. J.: Willingly and Knowingly, LEMMA Publishers, The Netherlands, 2000.
Wolf, J.: Comparison of two potato simulation models under climatic change, I. Model calibration and sensitivity analysis, Climate Res., 21, 173-186, 2002.

Xu, Z. W., Liu, S. M., Gong, L. J., Wang, J. M., and Li, X. W.: A study on the data processing and quality assessment of the eddy covariance system, Adv. Earth Sci., 23, 357-370, 2008.

Yang, Y. M., Yang, Y. H., Moiwo, J. P., and Hu, Y. K.: Estimation of irrigation requirement for sustainable water resources reallocation in North China, Agr. Water Manage., 97, 1711-1721, 2010. 